Article

\title{
OF SUBALTERNS AND SAMMI TREES: ECHOES OF GHADAR IN THE PUNJABI LITERARY MOVEMENT
}

\author{
SARA KAZMI
}

\begin{abstract}
This paper explores how the Ghadar legacy is interpreted by the Punjabi literary movement in Punjab, Pakistan. Putting Ghadar poetry into conversation with the work of these contemporary activists sheds light on unexplored facets of both. It unveils how these writers and thespians invoke Ghadar to subvert the narrow discourse of "Punjabiyat" and ethno-nationalist identity, and allows us to appreciate the politics of language that underpinned Ghadar di Goonj. The intertwining of these histories of literary dissent raises key questions for debates around radical literature and progressive writing in South Asia, by highlighting the role of vernaculars in reading subaltern consciousness and native traditions of revolt.
\end{abstract}

\section{Keywords}

Ghadar, Punjabi movement, Punjabi, language politics

\section{Introduction}

The air is cold but the sun shines bright onto the mud courtyard. The surrounding walls are neatly scrubbed, mud and thatch, enclosing a group of around 50 women, young and old, with their eyes trained onto a lean man clad in blue, and a vivacious young girl in pink. Some among the audience whisper fervently into each other's ears, discussing the tale unfolding, others seem a bit confused, if not bored, with their fidgety, frollicky children giving them a hard time concentrating on the dialogue: "He is a Ghadri, he is fighting a war against the English. We have to throw the English out. We want to bring the rule of the poor, remove the hold of the ruling classes, bring back the relations between people, what they make and what they eat."' (Syed 2004, 10)

A contemporary Punjabi play, Sammi di Vaar is being performed in a small village in Chakwal by the Sangat troupe, the small but active group of intellectuals and artists who constitute a Marxist stream within the Punjabi movement. The director, Huma Safdar, addresses the audience before the performance, introducing them to the play which presents a creative re-telling of an important chapter in Punjab's history of revolt, weaving in the narrative of subaltern groups,

\footnotetext{
${ }^{1}$ The translation of Sammi di vaar into English was completed by myself and Virinder Kalra.
} 
fisher (wo)men and faqirs with the larger history of anti-colonial resistance embodied by the Ghadar movement in South Asia.

Safdar is in her late fifties. Silvery wisps of hair frame her face, her green eyes dancing as she talks about Ghadar with her audience, who are perhaps only hearing the word for the first time. Politicised by the women's movement in the 1980s, she has dedicated herself to Punjabi street theatre for the past twenty years. On a recent trip to East Punjab where her students staged a Punjabi production on Baba Farid's life ${ }^{2}$, she described Punjabi as "the language of love, activism and art ... untouched by the elite"(Indian Express 2015). She has also recently completed a Potohari translation of Dada Ameer Haider's autobiography, an Indian communist who connected with the Ghadar Party in New York in 1920, and began distributing copies of Ghadar di Goonj at different sea ports across the world. His birthplace, a small village in Rawalpindi, is only an hour's drive from Chakwal.

Huma Safdar remains one of the leading members of Sangat. At the core of their praxis lies a theoretical approach which a) links language essentially with class, and b) critiques the cultural politics of the organized Left in Pakistan for their use of an elite language (Urdu), and for ignoring local traditions of dissent. The group engages folk forms and subaltern history as tools for commenting on contemporary politics. They believe that only a rooted revolutionary subject can connect with the oppressed classes of Punjab. In the Sangat's imagination, the Ghadar movement provides a template for this revolutionary subjectivity.

This paper explores the interpretation of the Ghadar legacy in contemporary West Punjab. Invoking its transnational history and universalist politics allows these activists to subvert the narrow discourse of "Punjabiyat" and avoid being reduced to an ethno-linguistic and nationalist movement in a country where Punjab remains the dominant region. An analysis of the language and symbolism in Ghadri poetry reveals how Ghadar's cultural politics connect with the Punjabi movement through an understanding of Punjabi as a working class language, a vessel for channeling pre-colonial traditions of resistance. This also allows an appreciation of the anticolonial politics of language which underpinned Ghadri poetry, an aspect which has remained unexplored.

Once viewed in that framework, an interesting exploration of the language politics of these texts becomes possible, one which links colonialism, class and radical cultural politics in a new and refreshing interpretation of the poetry of Ghadar and of the Marxist Punjabi movement.

\section{Ghadar di Goonj: a poetics of vernacular rebellion}

The Ghadar Party was a transnational organization founded by poor Punjabi immigrants settled in the Americas in the early $20^{\text {th }}$ century. As many commentators have maintained, the party organ, Ghadar, was integral to the anti-colonial praxis of the movement. Ramnath has shown

\footnotetext{
${ }^{2}$ Fariduddin Ganjshakar was a $13^{\text {th }}$ century Punjabi poet. His poetry has also been included in the Granth Sahib, the Sikh scripture.
} 
how the paper connected diaspora members across Hong Kong, Shanghai, Tokyo, Yokohama, Manila, Rangoon, Panama City, Seattle, and Vancouver. Kamran highlights how: "The concept and memory of Ghadar was so powerfully ingrained and deeply associated with [the] newly formed Hindi Association of the Pacific Coast and, perhaps, because of its widely distributed organ Ghadar, the party itself was, later, named as the Hindustan Ghadar Party" (Ahmad 2013).

Thousands of copies were published and circulated in the diaspora and abroad, and the paper was banned promptly by the authorities. Although initially in Urdu, Ghadar soon began to be published in Punjabi, in both the Shahmukhi and Gurmukhi scripts. While intellectuals within the movement such as Lala Hardayal contributed prose (written in Urdu and then translated into Punjabi by Kartar Singh), it is the sheer volume of poetry, predominantly in Punjabi, which has become an icon of Ghadar's cultural legacy.

These poems were later compiled and published as an anthology titled Ghadar di Goonj. They were not produced by ideologues or intellectuals, and were the work of ordinary party workers: the laboring men and landless peasants who re-enacted in moving verse their experience of oppression, their "coolie" subjectivity, their hope in the victory of India's downtrodden over the colonial masters.

The poetry draws generously on the language of tradition. Kalra points out how in the poetry, religious identities are almost always evoked to be condemned, calling on the reader to overcome communal differences to unite against the oppressor (Kalra forthcoming). For example, one poet writes how "we do not need pandits or kazis for we do not want our ship to sink/ the time for prayers and contemplation is past, it is time to raise the sword" (Tatla 2013, 63). Another poet states:

The Guru established the Panth for selfless service, He fought a marvellous battle To remove tyranny from India, battles on many fronts

For this Hind, millions sacrificed their lives, it is we who have forgotten the cause The Tenth Guru sacrificed his whole family, along with Nabbi and Ganni Shah for the cause (Kesar 1995, 94).

Hence, while the language of tradition does appear in the poetry, it is reworked and appropriated by the Ghadri poets to narrate a history of revolt.

This kind of re-interpretation of spiritual and regional heroes also defines the literary method of Najm Hosain Syed, who has been described as the "fountainhead" (Ayers 2009, 69) of the Punjabi movement in Pakistan by Alyssa Ayers. Syed began writing in the 1960s, and has published over thirty books of poetry and drama in Punjabi. His play Takht Lahore is based around the life of Dullah Bhatti, who was allegedly hanged by the Emperor Akbar for rebelling against the Mughal state. Interestingly, Dullah Bhatti never appears as a character in the play. He is instead employed as a symbol of rebellion, and while all the revolutionary action in the play takes place in his name, it is carried out by nameless factory workers and subalterns. Second, there is a deliberate obscuring of geography in the play. The word "Punjab" is not uttered once, so Dullah's rebellion hardly 
appears as a chauvinistic assertion of Punjabi power against Mughal hegemony. It is framed explicitly as a challenge to "kingship itself" and the "regime of property and wealth" (Syed 1972,154).

To reiterate, Takht Lahore commemorates Dullah Bhatti's rebellion for its radical political character, not for its celebration of a Punjabi ethnic pride. This echoes Ghadar's method, where references to Punjab, historical Sikhism and local spirituality are not used to affirm a religious, ethnic or regional identity. Instead, they constitute "a form of political articulation," that connected deeply with pre-colonial histories of resistance: (Kalra forthcoming)

Just citing the wonderful, the wonderful guru, have not we actually forgotten the political know-how?

He had vowed to destroy injustice and tyranny, and gave his own life for the cause!

In the cause, young sons he sacrificed, have you forgotten guru's command?

Read again his indicts, the glorious deeds, and the commands of our great guru

And come to the battlefield, let us dedicate life and drink the nectar of Ghadar -the rebellion! (Kesar 1995, 98)

Despite the clearly subversive use of tradition in Ghadar di Goonj, Tatla reads it as a "Sikh manifesto," citing references to the likes of Guru Gobind Singh, Hari Singh Nalwa and Tegh Bahadur as invocations of what he terms the heroic Sikh tradition of the $18^{\text {th }}$ century (Tatla 2013, 61). In a similar vein, Parmbir Gill has pointed out the Ghadris' use of religious symbols for inviting the Punjabi masses to rebellion, concluding that an essentially Sikh consciousness informed the poetry (Gill 2013, 23-41). These reductive readings are produced by, and help reproduce the marginalization of Ghadar in both nationalist and Leftist narratives. They reflect an inability to grasp what Ramnath terms the "jagged edges" of Ghadar and its legacy. Evading neat categorization, the "eclectic ideological synthesis" (Ramnath 2015, 28) presented in Ghadar di Goonj refuses to be reduced to a "Sikh manifesto." Its revolutionary poets happily drew from "a variety of sources, combining them without concern for the constraints of any existing orthodoxy," (Ramnath 2015,28) selecting and adapting tactical and ideological content into a dynamic, yet consistent form throughout the course of their struggle (Ramnath 2015, 28). While orthodox Marxist analysis has been wont to dismiss Ghadar's political orientation as "untheorised hodgepodge," (Ramnath 2015,28) a close reading of its poetry reveals a powerful compounding of socialism and anti-imperialism with pre-colonial histories of peasant rebellion. The poetry represents a unique moment in Punjab's intellectual history, a mode for radical thinking that critically informed traditions of literary dissent in colonial South Asia.

A similar fate has met the radical texts produced by the Punjabi movement. Despite the clear challenge to state and authority articulated in Syed's Takht Lahore, the play has been read as an articulation of a newfound "Punjabiyat," embodied by an image of a masculine, valourised Punjab which is "valiant and unfazed by authority" (Ayers 2009, 76). The Punjabi movement has 
been interpreted solely within the frame of ethno-nationalism, described as having risen out of the "shadowy political movements for regional autonomy" (Shackle 1970, 266) that characterized national politics in Pakistan in the 1960s. While the work of intellectuals within the Punjabi movement echoes Ghadar di Goonj through its soldering of folk narration with socialist emancipation, the intervention posed by these texts has never been placed in dialogue with the Progressive Writers' Movement, an organization that championed Marxist-inspired writing in Urdu and has remained the subject of much commentary on modern Left-wing movements in South Asia. ${ }^{3}$ Emancipating the Punjabi literature produced by Ghadar historically and the Punjabi movement today from the shackled view of "Sikh consciousness" and "Punjabiyat" exposes an alternative genealogy of literary dissent in the region which connects subaltern history, vernacular expression and local culture with contemporary class struggle. It also allows us to analyse Ghadar di Goonj as a discursive site for radical language politics in the colonial period.

\section{Imperial linguistics: language, colonialism, class and power}

The marginalization of the poetry of Ghadar and the Punjabi movement in literature on radical literature and cultural politics in South Asia stems from the colonial restructuring of the relationship between language and society. As Cohn demonstrates, colonial knowledge about languages institutionalised the so-called distinction between "classical" and "vulgar" tongues (1996). For example, the Persian department was the most prestigious at Fort William College, as Persian, Sanskrit and Arabic were considered comparable to the classical European languages of Greek and Latin, worthy of scholarly study (Cohn 1996, 24-25) On the other hand, commonly spoken languages were understood as "fallen, broken, or corrupt versions of some pure, authentic, coherent, logically formed prior language..." (Cohn 1996, 33). Despite the contempt for the spoken languages of India, the instrumentalities of rule dictated that the regime train its officers in certain vernaculars, the prime example being Hindustani. This was developed especially as a "language of command" (Cohn 1996, 33) to marshal the "lowly servant and sepoy" (Cohn 1996, 33). Due to this practical utility associated with Hindustani, later known as Urdu, it was taught widely to British officers, increasingly replacing Persian at the lower levels of administration after 1837 (Cohn 1996, 33). Thus, Persian along with Arabic and Sanskrit retained its scholarly and literary status (Rahman 2011) as a "classical tongue," meanwhile Urdu became the language of colonial government.

Thus, high culture and statecraft became the sole preserve of the "classical tongues" and "languages of administration," by implication placing vernaculars like Punjabi at the lowest rung of this linguistic scheme. These functions also endowed the classical and administrative languages with a public and universal nature which was denied to vernaculars. Kaviraj highlights the dual

\footnotetext{
${ }^{3}$ See for example, Ali, Asdar, Kamran. 2017. Surkh Salam: Communist politics and class activism in Pakistan 19471972. Karachi: Oxford University Press and Ahmed, Talat. 2009. Literature and politics in the age of nationalism: The Progressive Writers' Movement in South Asia 1932-56. New Delhi: Routledge.
} 
nature of these languages, which were public to insiders and closed, esoteric for those who lacked the requisite skills, i.e. spoke and understood only languages like Punjabi, Pashto or Sindhi (2005). For him, the political implication of this was "that while elite discourse could range across the entire subcontinent, the discourse of the subaltern groups necessarily remained trapped in the closed boundaries of their vernacular dialects" (Kaviraj, 319). While Kaviraj here is indicating the geographical limits of subaltern discourse, subaltern languages also came to be subjected to ideological confines. In other words, while elite discourse in the nationalist languages of Urdu and Hindi, or the official language of English could address questions of politics, culture and identity that ranged across the entire sub-continent, vernacular expression was necessarily "localized" in its ideological purview. It was deemed capable of articulating only a very particular, regional subjectivity, grounded in local, provincial politics, incapable of a universalist orientation. That is why Ghadri poetry, composed overwhelmingly in Punjabi, is read as a "Sikh manifesto" rather than an anti-colonial literature of resistance, and why plays like Takht Lahore are analysed from the lens of "Punjabiyat," despite Syed's clear use of "Marxist-inspired literary methodologies" (Kalra and Butt 2013).

In this way, colonial linguistic policy created the conditions that marginalized cultural production in the vernacular.

\section{Language and the nation: postcolonial continuities}

Colonial policy around language also caused Urdu to become a desirable commodity in North India on account of the prospects of government employment it brought (Rahman 2011). The colonial state's need for Indian scribes and functionaries educated in the language of administration led by the mid- $19^{\text {th }}$ century to the creation of what Hamza Alavi has termed the "salariat," a class of urban-based professionals, sections of which would later play an important role in the Pakistan movement (Alavi 1988, 68). Their distinct identity as the "governing class" which also served the interests of the "economically dominant classes" through their "direct grip over the colonial state apparatus" (Alavi 1988, 68) was cemented through the cultural bond of Urdu, the language they spoke, wrote and worked in, and also came to enjoy in literature, music and theatre. ${ }^{4}$ Language, culture and economic status thus came together in the social reproduction and self-identity of this group.

The emergence of Urdu as a prestige symbol also impacted its status vis a vis other languages, reflecting the power of the salariat in relation to other groups in society (Saqib 2004). In colonial Punjab, "upper classes and educated people spoke Hindustani," while Punjabi was the language of the "peasantry and lower classes in town only" (Rahman 2011,216). In this context,

\footnotetext{
${ }^{4}$ For an account of the shift from the vernacular language to Urdu in $19^{\text {th }}$ century Indian theatre, an important cultural site through which the emergent middle class reproduced itself, see Hansen, Kathryn, "Languages on Stage: Linguistic Pluralism and Community Formation in the Nineteenth Century Parsi Theatre," Modern Asian Studies 37, No.2 (2003): 381-405.
} 
the overwhelming domination of Punjabi in the poetry of Ghadar di Goonj reveals the complex relationship forged between language and class under colonialism. Punjabi lay outside the colonial state and its education system, which explained the profound suspicion with which the colonial mind viewed it, as evinced by the following quote from a British officer writing about Udham Singh: "...sentiments which are typical of a half educated Ghadar Revolutionary, in which words aspire to the Ghadar poetical compositions in which truth is subordinate to the flow of language" (Quoted in Ramnath 2015, 32). Read against the grain, the accusation that this "half educated" poetry subordinates truth to its "flow of language" betrays a fear of Ghadar's poetic power, a power which rested on its working class language that could connect immediately and intimately with the masses and was outside the knowledge controlled and created by the elite.

After the fruition of the Hindi-Urdu controversy, ${ }^{5} \mathrm{Hindi}$ and Urdu increasingly came to dominate as the languages of Indian and Muslim nationalism in North India, going on to take their places as the national languages of the nascent nations, India and Pakistan. The Indian National Congress and the Muslim League took centre-stage, and with all the might of the state, got to work erasing alternative histories of anti-coloniality.

The marginalization of regional languages went hand in hand with this project. By sidelining the role of regional culture in building national identity, the postcolonial states simultaneously silenced the politics and ideology contained in vernacular expression. One such victim was Ghadar. Ghadar's subversion and critique of bourgeois nationalism was expunged from the national consciousness. The scope of its poetics, articulated almost entirely in Punjabi, was "trapped within the confines of its vernacular dialect," reduced to an emblem of "Sikh consciousness" despite its universalist political orientation. The goonj, or echo of Ghadar became an inaudible whimper.

However, its surviving reverberations would be picked up in 1960s Pakistan, with the birth of a literary movement that combined rebel peasant consciousness and radical language politics in a historical tradition of resistance that stretched back from the Mazdoor Kissan Party to Ghadar, and all the way to the pre-colonial institutions of radical Sufism in Punjab.

\section{The Punjabi Literary Movement}

The origins of Punjabi language activism in Pakistan can be traced back to 1947. In the early years, prominent members of the Punjabi elite began campaigning publicly for its recognition as a language of the state. In 1951, Hameed Nizami, editor of the Urdu daily, Nawa-i-Waqt, penned an article in favor of Punjabi's adoption as the medium of instruction, while Hafeez Jalandhari, prominent Urdu poet, wrote poems in Punjabi and recited them with much gusto at rallies for the

\footnotetext{
${ }^{5}$ The Hindi-Urdu controversy developed in the late $19^{\text {th }}$ century in North India over the need to distinguish between "Hindi" and "Urdu" as two distinct languages belonging to two distinct communities, Hindu and Muslim. Historically the distinction between "Hindustani," "Hindi" and "Urdu" was not emphasized. For more detail see King, Stephen. 1995. One language, two scripts: The Hindi movement in $19^{\text {th }}$ century North India. Oxford: Oxford University Press
} 
rights of the mother tongue. ${ }^{6}$ This particular strand of Punjabi language politics lived a short life, as the Punjabi elite soon abandoned its fears of being sidelined by their Urdu-speaking compatriots, and wholeheartedly embraced the project of Pakistani statehood. In fact, Hameed Nizami's newspaper would emerge as the most vociferous critic of organisations like the Punjabi Majlis and Punjabi Writers' Guild in the 1950s. Nawa-i-Waqt ran a media campaign that branded Punjabi writers as anti-patriotic "traitors," accusing them of plotting to replace the Shahmukhi script with Gurmukhi, the script associated with the Sikhs (Rahman 1996). Both organisations were banned by the repressive military regime of Ayub Khan, in 1959 and 1963 respectively (Rahman 1996).

As Tariq Rahman has identified, vernacular expression occupied a subversive space in Pakistan's early days, and most intellectuals populating the ranks of the Punjabi writers were Leftleaning and progressive (Rahman 1996). Prominent amongst them were Shafqat Tanveer Mirza, who asserted that "in order to de-class oneself, one must first de-class one's language" (Saqib 2004, 347). Others included Najm Hosein Syed, Maqsood Saqib and Ishaque Muhammad. Muhammad was the chairman of the Mazdoor Kissan Party (Workers and Peasants Party), a Maoist organization focused on peasant politics which emerged in 1968 when the National Awami Party (NAP) split along Sino-Soviet lines (Ahmed 2010). His figure brought together literature and politics, inspiring a distinct tradition within Left-wing cultural politics in Pakistan.

Ishaque Muhammad's main literary works include two plays written in Punjabi, Quqnus and Mussali.' Quqnus, like Syed's Takht Lahore, is based on the historical figure of Dullah Bhatti. The play makes heavy use of folk songs and Punjabi poetry by the likes of Bulleh Shah, Shah Hussain and Waris Shah, grounding an invitation to revolutionary struggle in the historical, cultural and linguistic context of the Punjab. This "instrumental" use of Punjabi as a "mobilisational tool" (Butt and Kalra 2013) was an important aspect of the MKP's Maoist inspired line which sought that its "philosophy, strategy and tactics may be communicated to people... in a simplified and easy to understand manner" (Muhammad 1978, 306). The MKP's founding was undoubtedly influenced by the rising prominence of Maoist ideas internationally. However, Kamran Asdar Ali points out that it also represented the fruition of a critical strand within Pakistani communism in its early years, articulated most forcefully by Eric Cyprian, an old Communist Party of India (CPI) member who later came to associate with the MKP (2013). Cyprian criticised the nascent Communist Party of Pakistan (CPP) for its urban emphasis, advocating instead for organising the landless peasants and migrants in West Punjab (Ali, 490). The CPP on the other hand, based its strategy on a class analysis of Pakistan which categorised the country as a capitalist one where socialism was the next step, and hence, concentrated on the urban,

\footnotetext{
${ }^{6}$ Personal interviews with Maqsood Saqib and Mushtaq Soofi, conducted circa May 2016.

${ }^{7}$ See Muhammad, Ishaque. 2008. Ishaque Muhammad De Dramay. Lahore: Saanjh Publications.
} 
industrial working class. The CPP thus focused largely on trade union activity in the urban centres. $^{8}$

This difference of opinion also arose from a conflict between Punjab's communist tradition and that of the migrant leadership of the CPP, who had travelled to Pakistan from the United and Central Provinces when the party was divided along communal lines in 1947. This "Punjabi communism," for want of a better word, was heavily shaped by the ideology and practice of the Kirti Kissan Party, which was at the forefront of Punjabi anti-colonial resistance in the 1930s (Ramnath 2011), and subscribed to a similar emphasis on the countryside and on agrarian agitation against the Raj and its collaborators.

Thus, the MKP developed both a mobilisational and an ideological interest in Punjabi. Very little Urdu was spoken and understood in the countryside, which necessitated an instrumental shift to Punjabi for the party's cadre which was mostly urban. Second, Punjabi was also being understood as a doorway into the cultural world of the peasant, which was critical to building a rooted struggle that resonated with people's traditions and beliefs. Muhammad wrote in the preface to his play Mussali:

As part of living in a village and interacting with musallis... Firstly, I thought that they were always speaking in a free poetic form, but when needed they could play with words to maintain the flow. Waves of words flowed whatever the topic, ranging from the plough to love affairs. Secondly, the range of this language surprised me, these people who had been kept away from pathshalas, madrassas and schools, and for whom words were kept out of reach. They had a full command of their own language. Sitting in their school I became convinced about the importance of Punjabi (Muhammad 2008, 13).

Najm Hosein Syed and Maqsood Saqib were his close associates, and began their own journeys towards radical language politics in the same period. Syed wrote and composed revolutionary anthems in Punjabi which were recited at MKP's rallies' in Punjab's villages, while Saqib was closely involved with editing the party's Punjabi magazine, Ruth Lekha. After wrenching control of around 140 hectares of land in a peasant struggle in Hashtnagar, the MKP gradually went into decline, particularly following the death of Ishaque Muhammad in 1986.

While political organization in the countryside has suffered, as members of the Sangat, Syed and Saqib have been critical in keeping the radical cultural practice linking language, peasant consciousness and political dissent alive. Their "Marxist-inspired literary methodologies" (Butt and Kalra 2013) seek to consciously incorporate marginalized histories like that of Ghadar, whose poetry, in their analysis, presents the most pristine synthesis of language, culture and revolutionary politics.

\footnotetext{
${ }^{8}$ See Malik, "Narrowing Politics: The Labour Movement in Lahore 1947-74," Unpublished doctoral thesis, SOAS (2013).
} 


\section{Sangat: radical cultural practice in contemporary Punjab}

The poetry of Guru Nanak and Bhai Gurdas is sung and read in the weekly Punjabi poetry meeting held at Najm Hosein Syed's house, as well as in public performances by the Sangat troupe. Vaars and shloks which emphasize political resistance dominate the repertoire of the Sangat group, for instance, the following verses of Guru Nanak were sung at a performance in Malka Hans, near Sahiwal, on a performing tour undertaken by the group:

If you want to play love,

Then come to my street with your head held on your palm,

Once you set foot on this path

Then sacrifice your head, do not turn your back. ${ }^{9}$

This approach resonates with the Ghadri poetry discussed in the previous section, which reinterprets the Sikh past as a history of speaking truth to power, a reversal of the loyalist narrative of Punjabi history. A play titled Ik Raat Ravi Di, penned by Najm Hosein Syed and directed by Huma Safdar, ${ }^{10}$ similarly delves into the armed rebellion of Ahmed Khan Kharral in 1857. While dominant historiography on the subject identifies Punjab as a major collaborator in the 1857 uprising, Syed's play makes a nuanced distinction along the lines of class, positing that while the Punjabi elite threw in their lot with the British, the subaltern classes resisted British authority and maintained a militant anti-colonial outlook. ${ }^{11}$ The Punjabi movement evokes Ghadar and its legacy to challenge colonial historiography, as well as the nationalist narrative sanctioned by the Pakistani state. As Jalal points out, regional histories were suppressed (Jalal 1995) in favor of forging a national identity premised solely on Islam and Urdu. Through her analysis of Pakistani textbooks, she reveals how the distinct responses of the Baloch, Sindhi and Pashtun to colonialism were written out of nationalist history, to privilege a narrative that placed Muslim League, Urdu and Islam at the centre (Jalal 1995). While Punjab has dominated the state apparatus, with a preponderance of Punjabis in the armed forces and the bureaucracy, Punjab's regional history, language, culture and anti-colonial memory have not met with the same fate. The Punjabi movement's engagement with the legacy of Ghadar and revolutionary Sikhism thus has a twofold function. One, subverting Pakistani nationalism's surgical removal of the region's non-Muslim past, and two, a rejection of the chauvinistic "Punjabiyat" that has become the foundation-stone of the Pakistani state. Plays like Ik Raat Ravi Di and Chippan tohn pehlaan exhume histories of

\footnotetext{
${ }^{9}$ My translation.

${ }^{10}$ This play was performed at several venues including Punjab University in Lahore, in collaboration with Lok Rehas, circa 2006.

${ }^{11}$ A similar argument is made in a documentary directed by Huma Safdar titled "Come let's mend the torn cloth," which showcases folk songs and oral ballads around Kharral's confrontation with Lord Berkeley.
} 
rebellion that unsettle Punjab as the politically conservative ethnic hegemon, critiquing its contemporary position as the oppressor of Sindh, Balochistan, Khyber-Pakhtunkhwa and the Siraiki south from within.

Chippan tohn pehlaan is a play based on Bhagat Singh's life that was staged by Lok Rehas ${ }^{12}$ between 2010-11 and was directed by Huma Safdar. The performance began with a mime performed to a poem by Guru Nanak that emphasized the plight of the ordinary man, contrasting his life of hard labor with the accumulation of wealth. This play was performed extensively in Lahore, and in Sahiwal, Gujranwala and Kasur. Most provocatively, it was staged as a street play at Shadman Chowk on $23^{\text {rd }}$ March 2012, the square where Bhagat Singh was hanged by the colonial state on the very same date in 1931.

Bhagat Singh was a member of the Hindustan Socialist Republican Association (HSRA), and was in many ways directly influenced by Ghadar. As a student in Lahore, Bhagat Singh came into contact with many Ghadris, whose fiery lectures at the Bradlaugh Hall were recalled vividly by many of his comrades. ${ }^{13}$ He was hanged in Lahore in 1931 for assassinating John Saunders. He also shared his jail sentence with Baba Sohan Singh Bhakna, a key Ghadri figure, who was extremely old and feeble at that point but still joined Bhagat Singh and his comrades in their hunger strike, despite Singh's attempts to convince him otherwise. Bhagat Singh had modelled himself consciously on Kartar Singh Sarabha, a leading member of the Ghadar Party who was executed by the Crown in 1915 for instigating an anti-colonial rebellion. Sangat's street performance at Shadman Chowk, the site of his execution, thus re-enacted Ghadar's brand of guerilla tactics against the state in the postcolonial setting.

A great deal of controversy has come to surround Shadman Chowk in recent years, after some civil society members petitioned the state to rename it "Bhagat Singh Chowk" to honor the young anti-colonial nationalist. The state agreed, but promptly reversed its decision following protests from orthodox Islamic groups, who deemed the naming of a square in an "Islamic" country after a "Sikh" highly condemnable. Every year, civil society activists from different groups including the Punjabi movement, especially Lok Rehas, gather at the square to light candles and sing ghoris $^{14}$ to remember Bhagat Singh's sacrifice. The play was performed at one of these gatherings, and its fusion of Guru Nanak's work with that of a modern Marxist revolutionary like Bhagat Singh represents an important interpretive move by the Punjabi movement, one which links pre-colonial and colonial traditions of resistance into a local lineage of rebellion that threatens the state-sanctioned brand of Muslim nationalism.

In addition to theatre and weekly reading circles, writing, translating and publishing radical texts in Punjabi has also been integral to Sangat's attempt at articulating a transhistorical

\footnotetext{
${ }^{12}$ Lok Rehas is now a registered non-governmental organization, but it began in the 1980s as a street theatre troupe dedicated to performing only in Punjabi. Among other plays, it has also performed Syed's Takht Lahore, which was discussed above.

${ }^{13}$ A talk by Chris Mouffat at the Commemorating Ghadar conference at the Lahore University of Management Sciences, 2015. I am grateful to him for sharing the outline with me.

${ }^{14}$ Folk songs which depict Bhagat Singh in the idiom of the bridegroom. His martyrdom is usually the key theme.
} 
revolutionary subjectivity in Punjab. Ghadar and its legacy have figured prominently in these efforts. Maqsood Saqib published Baba Sohan Singh Bhakna's autobiography in the Shahmukhi script as a special edition of their monthly magazine, Puncham. This was also read together in a dedicated study circle in 2011. Further, in 2016, Huma Safdar published a Potohari translation of Dada Amir Haider's memoirs. As mentioned before, Haider was an Indian revolutionary who met with Ghadar Party members in New York in 1920 and became heavily involved with the circulation of Ghadar di Goonj globally. After the partition, Haider lived out his life in Rawalpindi, going to jail at least twice, for his defense of firebrand labour leader Hassan Nasir, and then for his political activities in the frontier province with MKP leader Afzal Bangash.

While the memoirs were penned in English, Huma's translation into not just Punjabi, but into the Potohari dialect of the northern Punjab that Dada Amir Haider belonged to demonstrates a very particular sensibility towards Punjab's revolutionary history. By translating from the language of imperialism to the vernacular, Safdar has attempted to return the history and intellectual lessons of Ghadar to the source of its radical potential, to the ordinary people and their culture of resistance where this anti-colonial movement found its roots. While the history of colonial language policy is the backdrop for Safdar's translation into Potohari, the contemporary linguistic context of Pakistan is also critical to understanding the radical cultural potential of this kind of language politics. The intimate link between class and language has continued to strengthen in postcolonial Pakistan. As Mansoor and Zaidi point out, Urdu remains a prestige symbol among the middle and lower middle classes in Pakistan, while Punjabi is seen as a marker of low socio-economic status (2005). Sindhi is used at the lower levels of administration only in a few parts of Sindh, while Urdu and English dominate in the armed forces, bureaucracy and judiciary alike in all other provinces of Pakistan (Ibid, 274-275). Despite the predominance of Punjabi speakers in the country, literacy in Punjabi is well below literacy in Urdu, to which employment is still tied inextricably (Rahman 2002). Translating the lessons of rebellion into the marginalized languages thus becomes a powerful way to reclaim the origins of a people's movement like Ghadar, and re-invent its legacy for emancipatory politics in the contemporary period.

\section{Ghadar in Syed's Sammi di vaar}

Sangat's re-enactment of the politics of Ghadar shows a unique linkage between language, culture, region and history to establish a genealogy of revolution drawing on local roots and vernacular ideology. Sammi di vaar, performed by the troupe between 2011 and 2015, perhaps warrants the most attention on account of its complex engagement with the memory and history of Ghadar. The play has been performed across Pakistani Punjab, in streets and in theatres, for audiences ranging from college students to peasants.

The year 1920 represented a pivotal moment in the history of the Ghadar movement. As Ramnath points out, contradictions within the original coalition which founded the movement 
were emerging, and the emphasis was shifting from the "blowhard intellectuals" to the "salt of the earth soldier-farmer-poets who were off to get things done" (Ramnath 2015, 43). In other words, Ghadar was developing a mass-based, popular orientation, which later on in the 1920s gives birth to the Kirti Kissan Party. The Kirti communists brazenly defied M.N. Roy's disciplining efforts in favor of a more "home grown" Punjabi communism, emphasizing a more vernacular approach which blended Sikh egalitarianism with a universalist socialism. This is the year Syed chooses to set Sammi di Vaar in.

The play opens with a wiry, emaciated old faqir, sitting in front of a fire which he tends to day and night. A young girl, by the name of Munni enters, and the rest of the play is simply a dialogue between the two characters, who are united through their connection to Dhuni. Dhuni had been Faqir's lover and the girl's grand-aunt.

The climax in the play occurs when Munni forces Faqir to recount the last time he saw Dhuni, who has now been missing for five years. In a dramatic narration, Faqir relays how Dhuni brought a Ghadri to his hut one day, telling him that he will stay the night and leave early next morning. In the night, as Dhuni, Faqir and the Ghadri sit around Faqir's flames, the small hut is raided by the police. They have been tipped off about the Ghadri's presence, and despite Dhuni's attempt to conceal him inside the hut, they drag him out and arrest him. At this point, Dhuni first tries to convince the police that they have the wrong man, offering up Faqir as the wanted revolutionary they are after. Seeing that they are not fooled, Dhuni throws herself between the Ghadri and the police. She puts up a great fight, but is ultimately handcuffed and thrown onto a horse alongside the Ghadri, who is revealed to be her lover. The police gallops off with the two prisoners, who are never heard from again.

And all this while, Faqir sits there, transfixed. His fear and inertia in the face of crisis, in the moment of decision when his comrade and lover needed him is what gnaws at him, day in, day out. It defines the nostalgia and loss embodied by his character.

The play, in structure and thematic emphasis, is very close to other historical dramas written by Syed. His purpose, in this depiction of Ghadar, is twofold. One, highlighting an alternative history of Punjab's political past which reveals an underlying continuity in the traditions of rebellion, to which he self-consciously joins his own work. Two, he aims to deconstruct the historiographical centrality accorded to a masculine "hero" or leader figure in not just folk, but also nationalist and Left-wing narratives. In Sammi di vaar, ordinary characters embody the rebel consciousness that drives revolution. In a nutshell, commemorating Ghadar for Syed has to involve a foray into its humble, subaltern origins, represented in Sammi di vaar through the nondescript setting of a small, quiet village in 1920s Punjab, with a minimalist structure resting on only two characters.

\section{Ghadar and the roots of resistance in Sammi di vaar}

The exchange between Faqir and Munni artfully weaves the everyday with deeper reflections 
on politics, society and culture. The two characters are tucked away cozily in a small hamlet shaded by trees, away from the main village. However, under the veneer of mundanity hides a thoughtful critique of colonial capital and state power:

Munni: Nani Dhuni, told me that we are not only fisher people but also boat's people, mallah, ferrying across the river. Ferry men spend the night on the river, while the women tend to the fire in the forests, rubbing the tree twigs together, just like you do. In those days, that tree was called Sammi. Out of the Sammi the sun was born. Sammi became the flame which lit up the city, its forts and mansions. The union of fire and water, the mallah and mallahni, the ferry people. The hookah, the shisha of the mallah might not have water but was always alight.

When the railways came, the ferries were no longer needed and the banks of the rivers were abandoned. The boat and fisher people moved to the settlements. Men started labouring and women sat at the tandoors (ovens).

Faqir: And the faqirs gave up showing the way of life giving breath and became slaves, and acquired the fire. Aaah, Dhuni, you never told me, the truth of this labour that I had made into mine, that became my bondage (Syed 2004, 12).

Ensconced in this oral history of the fishing castes is an indictment of colonialism in India. The British Indian railways were among the most intrusive and brutally transformative interventions by the colonial state. They served key imperial interests, providing speedy transportation for troops and their food supplies, plus raw material and British commodities. In addition to their practical use, the railways as colonial infrastructure also had symbolic power, representing by their spread and reach the penetration of the state and its control of Indian Territory. Railways were also the physical embodiment of the white man's civilizing mission, the emblem of modernity, the promise of progress being held out to the traditional, uncivilized Indian. And what of those who were brutalized by this colonial modernity, their voices silenced and footsteps erased?

The untold and unheard story of the ferry men narrated here highlights the "others" of colonial development. Their plight is also left out of the nationalist discourse, which focused mostly on the urban middle classes. As Bhattacharya has shown in his work on pastoralist communities in colonial Punjab, British laws which entrenched private land ownership increasingly excluded customary modes of land use, in which roaming pastoral groups enjoyed social ties with settled communities that entitled them to certain rights over the land (Bhattacharya 1998). However, with the Land Alienation Act and canal colonization, a contradiction developed between pastoralists and settled agriculturalists, leading ultimately to the stigmatization and criminalization of the former (Bhattacharya 1998). Similarly, Guha and Gadgil show that colonial forestry laws played an identical role in undermining traditional rights to the forest enjoyed by hill 
tribes (1995). The "ferry men" described in Sammi di Vaar saw a similar destruction of their livelihood. As the faqir laments, they went from being the guardians of fire and breath, the source of "life giving breath," and became "slaves."

The impoverished workers who boarded ships to Canada and America from Punjab, the coolies who swelled the ranks of the Ghadar Party also emerged from this process, as colonial transformations in agriculture and land use converted large sections of the Indian population into landless labour. The Ghadri in the play narrates a similar story. He appears as the product of this process of exploitation.

\section{Syed's 'absent' Ghadri: a case for subaltern agency}

...I am from Beas, the British laws mortgaged our land and in debt we became hungry and with some friends we went to Malaysia, then to America. We worked hard there and faced a lot of difficulties, but also came to realise how our country has been exploited by the English. We are a group of Ghadris that decided the time was right to return, so we came undercover, but many of us got caught, these nobles/ zamindars spy for the English after all, the Police are also after me... (Syed 2004, 20).

The Ghadri in Syed's play is not listed in the dramatis personae. He appears instead as a memory, when the Faqir recalls the day Dhuni left the village. The "Ghadri" appears as just that, and is not identified by his name, which brings into sharp relief Syed's framing of Ghadar's quintessential political subject. Further, his profile and lack of a name also suggests that he is not amongst the leaders or intellectuals of the Ghadar Party, whose names would go down in history and who bear a hierarchical relationship to the ordinary foot-soldiers in re-tellings of Ghadar's history. The Ghadar movement appears in perhaps its most unassuming form, a young man, alone, unidentified, on the run. He ties into the plot through his intimate relationship with Dhuni, and it is around her, not him, that the dialogue in the play revolves.

Syed artfully connects the small, quiet village with the internationalist Ghadar movement through the love between Dhuni and the Ghadri. He attempts to show how intimately Ghadri sentiment and ideology permeated the lives of ordinary Punjabis, and how passionately they responded to the demands of the movement:

Munni: (quoting Dhuni) I said to him, my Uncle was also a rebel, 60 years ago. Dhuni, said that Neeli bar and all along the Raavi is full of rebellious spirit, all of Dinpura supported Baba Ahmad Khan, except for these nobles. They gave horses to the English, got Ahmad Khan killed in secrecy... (Syed 2004, 20).

The emphasis on "all of the Neeli bar" and "Raavi" being Ghadri highlights the deep roots that Ghadar struck and its connection with subaltern agency. And these lines are relayed to us by 
Dhuni, who, even more than the Ghadri, is the one to embody the spirit of rebellion. Her name is derived from the word for "smoke," which rises from the home and the hearth, the centre of life in the village. Smoke itself is ephemeral, immaterial, yet it rises above, can travel great distances, and engulfs the population. "Dhuni," who is like smoke, is the collective consciousness, containing within it silenced histories and forgotten traditions, as well as the ability to conjure them into a new, political reality. This readiness for rebellion is emblematized by Dhuni's choice to leave the Faqir, her childhood lover, for the Ghadri. The young girl in the play, Munni, calls her "Nani" (grandmother), signaling an intimate relationship between them. Munni, whose mannerisms and physical appearances bear similarity to Dhuni, is like a reincarnation of Dhuni, the living, breathing, contemporary manifestation of a life force that animates the politics, tradition and history of the people. ${ }^{15}$ The continuity connecting Dhuni and Munni is symbolized by the Sammi tree, a plant indigenous to Punjab, fabled to be the source of life-giving fire produced by rubbing together its branches by the first women (not men!).

The Ghadri, through his connection with Dhuni, represents the powerful resonance that Ghadar had with vernacular traditions of resistance. It became a monumental transformative force because of the deep roots it struck in the subaltern consciousness. The play, in its interpretation of Ghadar, re-affirms the humility of its origins, instructing contemporary projects of emancipation in the need to reverse their top-down approach to the theory and practice of revolution. ${ }^{16}$ For Syed, understanding and learning from Ghadar cannot be done by ignoring its relationship to genealogies of dissent ingrained in the popular imagination, and it cannot be viewed through the lens of its leaders and upper-class intellectuals.

This is a recurring pattern in Syed's work. As mentioned before, Syed's play Ik raat Ravi di dramatizes Kharal's resistance. However, in the play, Kharal's mirasi appears as the most radical subject, the unsung low caste hero of an anti-colonial uprising. Kharal only has a few lines in the play, and the action pivots around the mirasi, who wryly remarks how Kharal would be remembered in folk songs and ballads to come, while he himself would be erased from history. Similarly, in Syed's Takht Lahore, Dullah Bhatti is not amongst the cast of characters. His work is instead carried out by nameless factory workers of "unknown origins, unknown parentage," (Syed 1972, 64) and the dissident poet of Lahore, Madhu Lal Hussain. Similarly, in Sammi di vaar, the Ghadri's appearance is brief, and we only hear from him directly once. The ideology and practice he represents is instead actualized by Dhuni and Munni, two bold and brave women, unlikely heroes for masculinist retellings of Punjab's anti-colonial history. Through these female protagonists, Syed deconstructs the hierarchical notion of leadership to understand the Ghadar

\footnotetext{
${ }^{15}$ This kind of a female figure, inspired by the goddess "Kali," or the mythological figure of "Kaal" makes a recurring appearance in many of Syed's plays and poems. Kaal is also the word for time, and the havoc-wreaking, bloodthirsty female that appears in ballads like Dulleh di vaar and Nadir Shah di vaar is frequently interpreted by Syed as the essence of revolutionary consciousness, which is essentially female and has been repressed through the ages.

${ }^{16}$ For Syed's stinging critique of Left-wing parties and organisational politics in Pakistan, see Haar de phull, a play in which bhaands, traditional comedians crash a rally organised by a workers' party and lead a hilarious expose of the leadership's shortfalls.
} 
movement, presenting a transhistorical theory of local rebellion grounded in the Punjabi context which views Ghadri radicalism as a product of subaltern consciousness and mass initiative. Thus, Ghadar for the contemporary Punjabi movement in Pakistan becomes a vehicle for subverting both a chauvinistic "Punjabiyat" and the reductive view of Ghadar as an identitarian "Sikh movement."

\section{Conclusion}

Thus, viewing Ghadar di Goonj and the Marxist Punjabi movement as parts of a shared trajectory of revolutionary writing in Punjabi expands the interpretive possibilities we attach to both. Ghadri poetry, when seen as a "form of political articulation" (Kalra forthcoming) rather than a crude mobilizational tool that pandered to religious identities, can begin to be placed in a comparative frame with the anti-colonial literature and art it shared a time period with. Discussions about the surge of nationalist literature in the $19^{\text {th }}$ and $20^{\text {th }}$ centuries in India, described by scholars as heralding the emergence of new "publics" where anti-colonialism, reform, resistance and tradition were debated have almost entirely focused on writing in Urdu, Hindi and English. These languages emerged as the sanctioned bearers of intellectual discourse in colonial society, regardless of which side of the ideological spectrum we are looking at (Kamran 2011). The poetry of Ghadar and that of the Punjabi movement has never been placed in conversation with these many "publics," barring us from appreciating these works as a part of histories of literary dissent in South Asia. Similarly, the poetry and theatre produced by groups such as Sangat and Lok Rehas can no longer be reduced to representations of "Punjabiyat," or of any form of ethno-nationalist identity.

Further, an analysis of the colonial context in which orientalist knowledge and administrative imperative combined to hierarchize, order and objectify languages produced a politics of language that was shaped by and in turn shaped the contradictions of class in society.

This linguistic politics was reflected clearly in the poetic praxis of Ghadar. Punjabi became the language of Ghadar di Goonj precisely because of this colonial linguistic context. This aspect has dominated in the Marxist Punjabi movement's engagement with Ghadar. Writing in Punjabi highlighted the class base of Ghadri support, distinguishing their struggle against the British from its elite counterpart that relied heavily on Urdu/ Hindi and English for articulating nationalist dissent. Thus, for the Sangat and the Punjabi movement, the radicalism of Ghadar's poetic form owes a great deal to its language, the language of the unlettered working class, that has always remained outside the avenues of power.

Putting Ghadar and the Punjabi movement in conversation through their literature and poetry thus proves fruitful in illuminating both. This is an aspect of Ghadari poetry which has remained unexplored, in part because language and politics in South Asia has invariably been viewed through the lens of nationalism, a theoretical link which this paper also attempts to unsettle. Language, once yoked with class, also opens the Punjabi movement up to radical interpretation. 
We can begin to read the Punjabi movement's texts as a quest for a rooted revolutionary subject by tapping into local traditions of dissent. These activists consciously link their language and cultural politics to a regional political tradition which unites the Ghadri rebels, Kirti Kissan Party, Bhagat Singh as well as pre-modern revolutionaries like Dullah Bhatti and Guru Nanak Dev. Ghadar and other local histories of rebellion become vehicles for engaging in cultural debates within the contemporary Left, shedding light on the ways in which the memory of Ghadar lives on amongst activist circles in Pakistani Punjab.

\section{References}

Alavi, Hamza. 1988. "Pakistan and Islam: Ethnicity and Ideology" in Fred Halliday and Hamza Alavi (eds.), State and Ideology in the Middle East and Pakistan. Palgrave Macmillan.

Ali, Asdar Kamran. 2011. "Communists in a Muslim Land: cultural debates in Pakistan's early years," Modern Asian Studies 45, 501-534.

Ali, Asdar, Kamran. 2013. "Progressives, Punjab and Pakistan: The Early Years," South Asian History and Culture 4, 4: 483-502.

Ayers, Alyssa. 2009. Speaking like a state: language and nationalism in Pakistan. Cambridge: Cambridge University Press.

Bhattacharya, Neelandari.1998. "Pastoralists in a colonial world," in D. Arnold and R. Guha (eds.) Nature, culture, imperialism: essays on the environmental history of South Asia. Delhi: Oxford University Press.

Cohn, Bernard. 1996. "The Command of Language and the Language of Command," in Colonialism and its Forms of Knowledge: The British in India. Princeton: Princeton University Press.

Jalal, Ayesha. 1995. “Conjuring Pakistan: History as official imagining," International Journal of Middle East Studies, Vol 27, No. 1, 73-89.

Kalra, Virinder and Butt, Waqas. 2013. “In one hand a pen, in the other a gun': Punjabi language radicalism in Punjab, Pakistan," South Asian History and Culture. 
Kalra, Virinder. Forthcoming. "Poetic politics: from Ghadar to the Indian Workers' Association," in R.S. Hegde and A.K. Sahoo (eds.) Routledge handbook of the Indian diaspora. New York: Routledge.

Kamran, Ahmad. 2013. The Ghadar Party I. https://thesouthasianidea.wordpress.com/2013/08/31/the-ghadar-party-i/

Kaviraj, Sudipto. 2005. "Writing, Speaking, Being: Language and the Historical Formation of Identities in India," in Asha Sarangi (ed.) Language and Politics in India. New Delhi: Oxford University Press

Kesar, K.S. 1995. Ghadar Lehar Di Kavita, Patiala: Punjabi University Press.

Gadgil, Madhav and Guha Ramachandra. 1989. "State forestry and social conflict in British India," Past and Present, 123, 141-177.

Gill, P. S. 2013. 'A different kind of dissidence: The Ghadar Party, Sikh history and the politics of anticolonial mobilization.' Sikh Formations, 10: 1, 23-41.

Mansoor, Sabiha. 2005. Language Planning in Higher Education: A Case Study of Pakistan. Karachi: Oxford University Press.

Muhammad, Ishaque. 1978. "Pakistan: Statement by Ishaque Muhammad, Chairman, Mazdoor Kissan Party, translated from MKP Circular No. 85," Journal of Contemporary Asia 8,2: 303-306, 306.

"Punjabi is the language of love, activism and art, says Lahore based thespian." December 2015. http://indianexpress.com/article/lifestyle/art-and-culture/the-essence-of-punjabiliterature-was-feminist-says-lahore-based-thespian/

Rahman, Tariq. 2011. From Hindi to Urdu: A Social and Political History. Karachi: Oxford University Press.

-----. 2002. Language, Ideology and Power: Language Learning Among the Muslims of North India and Pakistan. Karachi: Oxford University Press.

-----. 1996. Language and Politics in Pakistan. Karachi: Oxford University Press. 
Ramnath, Maia. 2011. Haj to Utopia: How the Ghadar Movement Charted Global Radicalism and Attempted to Overthrow the British Empire. Berkeley: University of California Press.

Saqib, Maqsood. 2004. “Mukh bol,” Pancham, Maa Boli no.: 342-360.

Saqib, Maqsood. 2004. "Lasaani Dhingaan da Mailband Pachokarr," Pancham, special edition: Ma Boli.

Shackle, Christopher. 1970. “Punjabi in Lahore,” Modern Asian Studies 4, no.3: 239-267.

Syed, Hosein, Najm. 2004. Khyaal Chaunkri. Lahore: Suchet Kitab Ghar.

Tatla, S., Darshan. 2013. “A Sikh manifesto? A reading of the Ghadar poetry," Punjab: Past and Present 44: 1, 61-81.

Zaidi, Abbas. 2005. “A Post-colonial Sociolinguistics of Punjabi in Pakistan,” JCPS 1, No. 3 \& 4. 